peculiarities of applying the methods of ascertaining experiment and theoretical modeling in philological diploma research; presentation of an ascertaining experiment and theoretical modeling as speech genres. The main method of research of the issue is the method of theoretical analysis of scientific literature.

The ascertaining experiment is interpreted as a method of finding new knowledge, and the method of theoretical modeling as such, which is based on the results of previously used empirical and theoretical methods and is a transition to the use of molding (educational) experiment.

The authors conclude that overcoming unilateralism in the choice of methods of diploma research is possible if to carry out purposeful and systematic training of students of features of empirical methods and their application. The research methods and description of the results obtained with their help are speech genres, characterized by a certain contentsemantic, stylistic and compositional unity. Content-semantic unity is ensured by unity of goals and content of tasks; stylistic - by characteristics of scientific speech; compositional by placing text components and links between them.

Teaching students to use empirical methods and describing their results will contribute not only to acquisition of new knowledge, but also to the development of research competence, which is the most important component in the structure of professional competence of the philologist.

Prospects for the study of the problem lie in developing a system of exercises (practical methods) for teaching students to use empirical methods, to create a theoretical model of the educational process as a basis for the design and implementation of a molding experiment.

Key words: diploma research, theoretical methods of research, empirical methods of research, ascertaining experiment, method of theoretical modeling, questioning, speech genre, description of the obtained results.

Удк 378.4.07:005.95]:008-028.42

Любов Пшенична

Сумський державний педагогічний

університет імені А. С. Макаренка

ORCID ID 0000-0002-2840-2189

DOI 10.24139/2312-5993/2019.08/270-288

\title{
АКАДЕМІЧНА КУЛЬТУРА ЯК ЧИННИК ЕФЕКТИВНОГО УПРАВЛІННЯ СУЧАСНИМ УНІВЕРСИТЕТОМ
}

\begin{abstract}
Стаття присвячена проблемі дослідження академічної культури, ії теоретичному обгрунтуванню, визначенню сутності поняття в контексті ії формування як чинника ефективного управління сучасним університетом. Для досягнення поставленої мети досліджено методологічні та теоретичні основи управління, $і$ зроблені висновки, що поняття управління та менеджмент утворюють синонімічні ряди: практику діяльності людини, професію, науку, прочес діяльності, людей які здійснюють управління, орган управління.

Процес управління розглянуто як вид діяльності, який забезпечує оптимальне функціонування та розвиток систем, узгоджує й координує діяльність людей щодо досягнення спільної мети, адже успішна діяльність університету в умовах автономії вимагає системного переосмислення підходів до нього як на рівні навчального
\end{abstract}


прочесу, так і в маситабах цілого університету.

Ключові слова: академічна культура, культура управління, менеджмент, сфера діяльності, університет, професійна діяльність керівника, системний підхід.

Постановка проблеми. Університет $\epsilon$ спільнотою студентів, викладачів, науковців, співробітників, об'єднаних спільним прагненням до знань, до розуміння світу; це сфера спілкування, яка збагачує знаннями, досвідом, допомагає знайти велику кількість однодумців, друзів, рідних за духом людей; університет - це місце де можна реалізувати себе...

Життєздатність та суспільний авторитет університетського співтовариства, яке позначає академічну культуру накопичення знань, їхнього розвитку, упорядкування та передачі від покоління до покоління через практиків та зберігачів, мережу установ і організацій, які цим займаються, а ще академічну традицію, і залежить від відданості тим цінностям, на яких вона будується. Так виникає академічна інституційна культура як поєднання способів і методів діяльності університетської спільноти, її системна інтегрована якість, що відображає досягнутий рівень розвитку; сукупність соціальних норм і цінностей, що генетично не успадковуються, а сформувалися історично і притаманні конкретній суспільній системі; певні явища, процеси, відносини, що якісно відрізняють професорсько-викладацький склад, студентів та адміністративногосподарський персонал закладу вищої освіти від інших спільнот та соціальних груп суспільства і $€$ результатом соціальної взаємодії; яка обумовлює спільні для цієї спільноти підходи до способу організації навчання, праці, визначення рівня посадової компетенції та довіри, процедури прийняття рішень, сприйняття та розв'язання конфліктів.

Розвиток, виховання, зміцнення академічної культури в діяльності закладу вищої освіти $€$ неодмінною умовою якісного менеждменту. Це вносить необхідну для прийняття управлінських рішень кадрову політику, ясність у залучення та розподіл бюджетних, спонсорських коштів та доходів спеціального фонду, планування діяльності та оцінювання ії результатів, комплектування бібліотечних ресурсів, створення належних умов навчання та проживання здобувачів вищої освіти у студентських гуртожитках, адже академічна культура - це не розкіш, яку собі може дозволити університет, коли все решта визначено і добре працює, це дуже практичний засіб покращити управління, забезпечити академічну якість і навіть фінансово оптимізувати діяльність університету.

Аналіз актуальних досліджень. Проблема формування академічної культури в педагогічному середовищі знайшла своє відображення в наукових працях Н. Гордієнко, Л. Мацько, А. Прохорова, А. Сбруєвої, О. Семеног, І. Сизової, В. Статівки, І. Томашевської, О. Фаст; цінності академічної культури: чесність, довіра, повага, відповідальність, традиції, морально-етичні, ціннісні, 
освітні їі аспекти розглянуто в наукових дослідженнях вітчизняних учених В. Астахової, Т. Добко, О. Єрохіної, В. Лугового, В. Ромакіна, О. Семеног, О. Смолінської; традиціям та новаціям у розвитку та становленні академічної культури присвячені наукові дослідження О.Висоцької, Ю.Громика, Л. Новаківської, М. Павленко, О. Сухомлинської; сутність способів і методів діяльності університетської спільноти, їі системна інтегрована якість, що відображає досягнутий рівень розвитку окреслені в доробках О.Габович, Ю. Грицевича, І. Левчук, В. Турчиновського, Г. Хоружого.

Зважаючи на актуальність окресленої проблеми, мета статті полягає в теоретичному обґрунтуванні сутності поняття академічної культури в контексті їі формування як чинника ефективного управління сучасним університетом.

У даній статті для досягнення зазначеної мети використано такі методи, як: аналіз психологічної, педагогічної, методичної літератури за проблемою дослідження, а також порівняння, узагальнення й систематизація матеріалів для виявлення сутності основоположних понять.

Виклад основного матеріалу. Будь-яка наука має власний предмет дослідження. Предметом науки управління виступають процеси та явища певних систем, які покликані щось виробляти або надавати певні послуги. щоб забезпечити ефективність управління, необхідно знати його методологічні та теоретичні основи. Для визначення діяльності 3 координації роботи людей на практиці використовують різні поняття: управління; менеджмент; адміністрування; керування тощо.

Управління - найбільш загальне поняття. Воно поширюється на велике коло різноманітних об'єктів, явищ і процесів: технічні, господарські, суспільні, державні системи тощо.

Термін «управління» - багатовекторний, він має кілька визначень:

В.Г. Афанасьєв: Управління - це передусім усвідомлена діяльність людини, яка переслідує свої цілі. І не просто діяльність, а той особливий їі різновид, який пов'язаний із виробленням рішення, 3 організацією, спрямованою на втілення рішення в життя, 3 регулюванням системи відповідно до заданої мети, 3 підбиттям підсумків діяльності, 3 систематичним отриманням, переробкою та використанням інформації.

Філософський словник: Управління - елемент, функція організованих систем різної природи (біологічних, соціальних, технічних), що забезпечує збереження їх певної структури, підтримку діяльності, реалізацію їх програм і мети.

Г. В. Єльникова: Управління - це особливий вид людської діяльності в умовах постійних змін внутрішнього й зовнішнього середовища, який забезпечує цілеспрямований вплив на керовану систему для збереження і впорядкування ії в межах заданих параметрів на основі закономірностей ії розвитку та дії механізмів самоуправління.

Б. М. Андрушкін, О. Є. Кузьмін: Управління - це цілеспрямована дія 
на об'єкт з метою змінити його стан або поведінку в зв'язку зі зміною обставин.

І.Ф. Ісаєв: Під управлінням взагалі розуміється діяльність, спрямована на вироблення рішень, організацію, контроль, регулювання об'єкта управління відповідно до заданої мети, аналіз і підбиття підсумків на основі дострокової інформації.

В. С. Лазарєв: Управління - це безперервна послідовність дій, що здійснюється суб'єктом управління, у результаті яких формується і змінюється образ керованого об'єкта, установлюються цілі сумісної діяльності, визначаються способи їхнього досягнення, розділяються роботи між ії учасниками та інтегруються їх зусилля.

М. Х. Мескон, Ф. Хедоурі, М. Альберт: Управління - це процес планування, організації, мотивації і контролю, необхідний для того, щоб сформулювати й досягти цілей організації.

В. П. Жигалов, Л. М. Шимановська:Управління - складний соціальноекономічний процес. У широкому розумінні слова він означає вплив на процеси, об'єкти, системи з метою збереження їхньої сталості або переведення з одного стану в інший згідно з поставленими цілями.

Сьогодення ставить високі вимоги до людського фактору в сучасному виробництві, освіті, державному управлінні, місцевому самоврядуванні, де однією 3 найважливіших функцій управління персоналом стає його розвиток, а не приведення його чисельності у відповідність до наявності робочих місць, що потребує іншого підходу до прийняття управлінських рішень. Це стало аргументом для виділення управління персоналом в окремий напрям менеджменту.

Менеджмент - це поняття використовують переважно для характеристики цілеспрямованих процесів управління людьми, який об'єднує визначення мети, явищ, процесів узгодження, поєднання різноманітних трудових операцій та докладання зусиль щодо її досягнення.

Тлумачний словник дає таке визначення менеджменту: Менеджмент - сукупність стратегій, філософії, принципів, методів, засобів та форм управління виробництвом з метою підвищення його ефективності та зростання прибутків.

У фундаментальному Оксфордському словнику менеджмент має такі визначення:

- менеджмент - це спосіб та манера спілкування з людьми (працівниками);

- менеджмент - це влада та мистецтво керівника;

- менеджмент - це вміння та адміністративні навички організувати ефективну роботу апарату управління (служб працівників);

- менеджмент - це органи управління, адміністративні одиниці, служби й підрозділи;

- 3 функціональних позицій менеджмент - процес планування, 
організації, мотивації та контролю, необхідний для формування і досягнення мети організації.

Ю. К. Конаржевський: Менеджмент - це нова філософія управління, яка виокремлює роль управління і менеджера в суспільному житті, а також соціальну значущість професії управляючого. Це вимога зробити процес управління цілком обґрунтованим, доцільним і складати плани досягнення цілей таким чином, щоб підлеглі працювали з усвідомлення власної гідності й отримувати від роботи задоволення.

А. С. Большаков: Менеджмент - це сукупність методів, принципів, засобів та форм управління організаціями 3 метою підвищення ефективності їх діяльності.

Узагальнюючи визначення понять, можна зробити висновки:

- поняття управління та менеджмент утворюють синонімічні ряди: практику діяльності людини, професію, науку, процес діяльності, людей які здійснюють управління, орган управління;

- управління - це вид діяльності, який забезпечує оптимальне функціонування та розвиток систем, узгоджує й координує діяльність людей щодо досягнення спільної мети;

- управляти можна системами, процесами; керувати - людьми, колективами.

Управління людьми здійснює керівник - це менеджер, який організовує, координує діяльність людей для досягнення професійних успіхів, результатів.

Ми поділяємо думку вчених-практиків, що одним із сукупності складових будь-якої організації, як цілісної освітньо-виробничогосподарської системи, поряд із управлінням діяльності $\epsilon$ управління персоналом. У науковій літературі можна зустріти різні варіанти структурування системи організації, але завжди виділяється кадрова складова як основна частина системи управління (Салова, 2013).

Зараз широко використовуються такі поняття, як: управління трудовими ресурсами, управління працею, управління кадрами, управління людськими ресурсами, управління людським фактором, кадрова політика, кадрова робота, які так чи інакше відносяться до трудової діяльності людини та управління його поведінкою в процесі виконання трудових обов'язків. Управління персоналом набуває дедалі більшого значення як чинник підвищення конкурентоспроможності установи, досягнення успіху в реалізації її стратегії розвитку.

За визначенням Г. Ковальова, цілями управління персоналом $€$ :

- підвищення конкурентоспроможності організації в ринкових умовах;

- підвищення ефективності виробництва та праці, а саме досягнення максимального прибутку;

- забезпечення високої соціальної ефективності функціонування 
колективу.

Успішне виконання поставлених цілей потребує виконання таких задач, як:

- забезпечення потреби організації в робочій силі в необхідній кількості та кваліфікації;

- досягнення обґрунтованого співвідношення між організаційнотехнічною структурою виробничого потенціалу та структурою трудового потенціалу;

- повне та ефективне використання потенціалу всіх учасників трудового процесу в цілому;

- забезпечення умов для високопродуктивної праці, високого рівня ії організованості, умотивованості, самодисципліни, вироблення у працівника звички до взаємодії та співробітництва;

- закріплення працівника в організації, формування стабільного колективу;

- забезпечення реалізації бажань, потреб та інтересів працівників по відношенню до змісту праці, умов праці, виду зайнятості, можливості професійно-кваліфікаційного та кар'єрного просування;

- узгодження виробничої та соціальних задач через балансування інтересів підприємства та інтересів працівників, економічної та соціальної ефективності;

- підвищення ефективності управління персоналом, досягнення цілей управління при скорочення витрат на робочу силу (Ковальов, 2000, с. 4).

Управління людськими ресурсами - головна функція будь-якої організації, адже персонал - найбільш складний об'єкт управління в організації, оскільки, на відміну від речових факторів виробництва, $є$ живим, має можливість самостійно приймати рішення, діяти, критично оцінювати пред'явлені до нього вимоги (Салова, 2013, с. 15).

Заклад вищої освіти є структурою, яка потребує високо кваліфікованих наукових та науково-педагогічних кадрів, а тому підхід до створення якісного складу повинен бути чітко спланований. Планування персоналу передбачає оцінювання наявних ресурсів закладу освіти; визначення можливих потреб у трудових ресурсах; вивчення ринку праці й розроблення програми залучення персоналу для задоволення потреб університету.

Якісний склад трудових ресурсів закладу вищої освіти тим вищий, чим більша частка працівників, які забезпечують високу продуктивність праці, тобто $є$ персоналом високої кваліфікації. Ця вимога забезпечується підбором персоналу - дій, спрямованих на залучення кандидатів, які володіють якостями, необхідними для досягнення цілей, що стоять перед закладом. Існують як внутрішні, так і зовнішні джерела підбору кадрового потенціалу. 
Кадровий потенціал - це трудові можливості підприємства, установи, організації, здатність персоналу до генерування ідей, створення нової продукції та надання якісних послуг, його освітній, кваліфікаційний рівень, психофізіологічні характеристики і мотиваційний потенціал (Комаров, с. 1). Термін «потенціал» означає наявність у персоналу, тобто кожної окремої людини, первинного трудового колективу, суспільства в цілому, прихованих, ще не проявлених можливостей або здібностей у відповідних сферах життєдіяльності. Під кадровим потенціалом розуміється міра здібностей і можливостей працівників матеріалізувати свої знання і вміння з метою забезпечення життєздатності і розвитку фірми.

До внутрішніх джерел ми відносимо: аналіз нині діючого складу працівників, визначення потреби в кадрах з урахуванням стратегії розвитку закладу вищої освіти; формування чисельного та якісного складу кадрів через систему планування, комплектування та розстановки кадрів; систему розвитку кадрів: їх підготовка й перепідготовка, підвищення кваліфікації, забезпечення професійно-кваліфікаційного зростання через планування трудової кар'єри; оцінку діяльності й атестацію кадрів, орієнтація ії на заохочення і просування працівників за результатами праці і цінності працівника для закладу вищої освіти.

Орієнтація на зовнішні джерела підбору кадрів закладу забезпечує створення власної бази даних потенційних кандидатів для заповнення вакантних посад через кадрові агентства, які володіють базами даних та сучасними методиками підбору персоналу, але це більше винятки, більшість вітчизняних закладів вищої освіти підбирають персонал самостійно.

Менеджмент забезпечення відповідності якісного складу працівників, що відповідатимуть рівню закладу вищої освіти, передбачає запровадження таких заходів:

- організаційні: реалізація очікуваних результатів за допомогою професійного розвитку працівників; удосконалення роботи щодо створення відповідних умов для розвитку та формування кадрового резерву закладів вищої освіти;

- удосконалення системи управління персоналом: опрацювання новітніх підходів до формування професорсько-викладацького складу, допоміжного складу; залучення до науково-педагогічної діяльності талановитої й обдарованої молоді, у тому числі із працівників закладу освіти;

- перспективний розвиток: забезпечення ефективності стажування та підвищення кваліфікації працівників.

Умовою виконання цих заходів $є$ збереження й підвищення потенціалу працівників, спадкоємність поколінь, позитивну кадрову динаміку, відповідність показників акредитаційним вимогам. Для забезпечення освітнього процесу і наукової діяльності ЗВО кадрами вищої кваліфікації потрібно підвищити професійне спрямування працівників до професійної діяльності. 
Кожен заклад вищої освіти має свою програму управління кадровим потенціалом, яка передбачає:

- постановка мети і завдань управління кадровим потенціалом: основна мета полягає в забезпеченні успішної роботи закладу в умовах ринкової економіки, а основними завданнями, що ставить перед собою університет на цьому етапі - це залучення кваліфікованих фахівців та кваліфікований розвиток персоналу;

- визначення учасників управління кадровим потенціалом: необхідною умовою рішення управлінських завдань $\epsilon$ наявність висококваліфікованого персоналу, готового до оволодіння новими знаннями. У зв'язку з цим зростає роль управління кадровим потенціалом як особливого виду діяльності, що включає: визначення потреби в персоналі; залучення персоналу; його відбір; розстановку персоналу; підготовку, перепідготовку, підвищення кваліфікації; мотивацію розвитку персоналу; оцінку ефективності управління;

- умови підвищення ефективності управління кадровим потенціалом: найважливішим завданням на цьому етапі управління кадровим потенціалом стає закріплення й розвиток персоналу, що передбачає: раціональний розподіл посадових обов'язків; професійне і посадове просування працівників з урахуванням результатів оцінки їх діяльності та індивідуальних особливостей; регулярне підвищення кваліфікації фахівців; створення інших умов, які б мотивували працівників до більш ефективної праці; планування кар'єри;

- оцінка персоналу (процедура, що здійснюється з метою виявлення ступеня відповідності професійних, ділових та особистих якостей працівника, кількісних і якісних результатів його трудової діяльності визначеним вимогам) - параметри, що характеризують професійну успішність працівника; вона використовується в таких сферах, як відбір і розстановка персоналу; планування і супровід діяльності фахівців; підготовка й підвищення кваліфікації працівників; формування, підготовка резерву для висунення на керівну посаду; удосконалення системи пільг, умов праці тощо.

Програма управління персоналом спрямована, у першу чергу, на його розвиток, який забезпечує:

- перехід до професійного управління людськими ресурсами;

- збільшення питомої ваги висококваліфікованих науково-педагогічних кадрів, спроможних реалізувати основні завдання, які стоять перед університетом;

- розробку та впровадження механізмів підвищення мотивації діяльності та безперервного професійного зростання науковопедагогічних і педагогічних працівників;

- упровадження та стимулювання заходів, спрямованих на відбір і залучення талановитої молоді з випускників магістратури до складу науково-педагогічних працівників Університету; 
- створення умов для функціонування аспірантури та докторантури 3 метою зміцнення наукового потенціалу закладу вищої освіти;

- відкриття спеціалізованих вчених рад для захисту дисертаційних досліджень науковців університету та педагогічних працівників закладів освіти;

- комплексне розв'язання соціально-побутових умов та встановлення щомісячної надбавки науково-педагогічним та педагогічним працівникам університету за складність та напруженість у роботі.

Успішна діяльність університету в умовах автономії вимагає системного переосмислення підходів до управління як на рівні навчального процесу, так і в масштабах цілого університету.

У контексті дослідження розглянемо поняття «культура». Існує чимало визначень поняття «культура», що свідчить про його багатозначність. Учені визначають різні підходи до розуміння визначення, яке стоїть за поняттям культура. На міжнародному філософському конгресі в 1980 році наводилося більше 250 визначень цього поняття, але різні джерела налічують їх до 500.

Великий тлумачний словник української мови також фіксує декілька основних значень та відтінків поняття культури - культура як: сукупність досягнень людського успільства у виробничому, суспільному й духовному житті; освіченість, вихованість, начитаність; наявність певних навичок поведінки в суспільстві; сукупність умов життя, необхідних освіченій людині; рівень досягнень у певну епоху якого-небудь народу або класу суспільства тощо (Комаров, с. 472).

Наприкінці XX століття у вітчизняній науці виникли два підходи до осмислення загальної природи культури. Один 3 підходів науковці А. Арнольдов, Е. Баллер, Н. Злобін, Л. Коган, В. Межуєв та ін. визначили як процес творчої діяльності, а В. Давидович, М. Каган, Е. Маркарян, В. Трушков, 3. Файнбург та ін. - як специфічний спосіб людської діяльності та зробили предметом свого дослідження питання, пов'язані із загальною характеристикою культури як універсальної властивості суспільного житт людей. Культура охоплює всі сфери діяльності людини у процесі їі розвитку, як у сфері матеріального виробництва, так і у сфері духовності. Вона - у знаннях людства, традиціях поколінь, у змісті життя і праці особистості, у її звичках, життєвому досвіді, нормах і принципах моралі, етики, естетики і права.

Разом із тим, під культурою розуміють рівень освіченості, вихованості людей, а також рівень оволодіння якоюсь галуззю знань або діяльності (Закон України «Про вищу освіту, с. 182).

Життєва аксіома стверджує: культуру створюють люди, сповідують їі теж люди, а тому феномен, який $€$ своєрідним інструментом успішної діяльності будь-якої організації, ії керівника, колективу, кожного співробітника є управлінська культура. 
У контексті дослідження розглянемо поняття «управлінська культура». За визначенням О. Яркового, управлінська культура розглядається як творча самореалізація етично-моральних переконань та ідеалів адекватно до правових норм управлінської діяльності (Ярковий, 2012, с. 8).

С. Королюк акцентує, що управлінська культура - це різновид професійної культури, який складається 3 політичної, правової, адміністративної, менеджерської, організаційної, соціально-психологічної, інформаційної, комунікативної та економічної культур і $\epsilon$ інтегральним утворенням щодо системи знань і вмінь, особистісних якостей, мотивів і цінностей, які реалізуються під час управління (Королюк, 2003, с. 88).

Розглядаючи вплив управлінської культури керівника закладу освіти Н. Святоха стверджує, що управлінська культура керівника закладу освіти це система інтегральних характеристик управлінських якостей керівника, що складається з ціннісних основ управлінської діяльності, гуманістично зорієнтованих моделей поведінки, відповідного стилю управління, інноваційних управлінських технологій (Святоха, 2013, с. 231).

Зміст управлінської культури полягає в сукупності досягнень в організації і здійсненні процесу управління, організації управлінської праці, використання сучасних методів і форм управління, інноваційних технологій, моральних, юридичних, економічних, організаційних, технологічних та етичних норм.

До основних елементів управлінської культури належать:

- управлінські знання, уміння й навички, а також відповідна самооцінка керівника, уміння керувати настроєм, емоціями, досвід роботи в даній сфері, витримка, здатність спокійно реагувати на провокації;

- етика та етикет керівника;

- суспільні відносини як управлінські, так і організаційні, у яких матеріалізуються норми, цінності суспільства та організації і які в процесі соціалізації особистості стають надбанням культури кожного;

- ступінь прийняття цінностей організації, установлених суспільством культурних норм.

На нашу думку, кожному управлінцю для досягнення висот управлінської культури, а отже і для забезпечення ефективності діяльності закладу вищої освіти в цілому, потрібно досконало оволодівати механізмами формування себе, як особистості, уміння реально оцінювати власні не лише сильні, але й слабкі сторони та цілеспрямовано працювати над удосконаленням своїх організаторських і професійних навичок, що забезпечить безперервне особистісне самовдосконалення для забезпечення ефективного управління людськими ресурсами в очолюваному колективі, адже за правилами американського менеджменту, у будь-якій справі 80 \% успіху залежить від керівника і тільки двадцять - від його підлеглих. 
У сучасних умовах функціонування закладів вищої освіти управління набуває особливого значення для успішної його діяльності, адже заклад може бути життєздатним лише завдяки особистостям і лише у світі особистостей, що ґрунтуються на формуванні знань, управлінських концепцій, проектів, програм тощо; розвитку управлінських відносин; мотивації творчої діяльності у сфері управління, утвердженні поваги в суспільстві до суспільних інститутів, держави, законів, моралі, права; виробленні та впровадженні управлінських технологій, які оптимізують сам процес управління і об'єднують в єдине ціле управлінські знання, відносини, творчу діяльність, роботу суспільних інститутів.

Управлінська культура $є$ складовою професійної (у нашому випадку управлінської) компетентності, яка визначається сукупністю знань, необхідних для певної педагогічної спеціальності або посади; умінь і навичок, необхідних для успішного виконання функціонально-посадових обов'язків; професійних, ділових і особистісних якостей для більш повної реалізації власних сил, здібностей і можливостей при виконанні функціонально-посадових обов'язків; загальної культури, необхідної для формування гуманістичного погляду, духовно-ціннісних орієнтирів, моральних та етичних принципів особистості; мотивації професійної діяльності (Мельник, 2003, с. 50-51).

Складовою управлінської культури є академічна культура управління, що включає в себе три види елементів:

- поняття, які характеризують академічну культуру як культуру університету і допомагають членам академічної спільноти організовувати високу якість праці та відповідальності за ії результати;

- відносини, що відображають ставлення до цінностей і способів поведінки, які є спільними для всіх, хто працює і навчається в університеті;

- цінності - елемент академічної культури, що являє собою систему культури особливої поведінки і спілкування людей, які професійно покликані забезпечувати трансляцію культурних цінностей, що лежать в основі моральних доктрин і поділяються всіма членами академічної спільноти.

Академічна культура не може бути перенесена чи запозичена, вона $€$ вистраждана ціною спроб і помилок, ціною постійної роботи університетської спільноти над собою, вона не $€$ раз і назавжди сформованою і сталою, а потребує постійного оновлення й удосконалення, а наполеглива праця над нею себе виправдовує стократ. Загально визнана управлінська академічна культура $\epsilon$ не лише візитівкою, а й відчутною конкурентною перевагою університету, бо створюється щохвилини, з перших кроків існування і $\epsilon$ дуже важливим чинником покращення управління, забезпечення академічної якості та фінансової оптимізації діяльності університету. 
Академічна культура управління включає в себе:

- високі вимоги до культури надання освітніх послуг в університеті;

- правильне ведення, оформлення та зберігання документації;

- правильну розстановка кадрів на вирішальних ланках, дотримання етичних і моральних норм взаємин із колегами, студентами, партнерами, роботодавцями;

- бачення кінцевої мети, дотримуючись найбільш раціональних методів ії досягнення;

- наполегливе оволодіння науковими принципами управління, уміле їх використання у своїй управлінській діяльності;

- виконання адміністрацією сукупності вимог, що висуваються до процесу управління, зумовлених нормами моралі, етики, естетики, права, принципами організації і технології управління;

- правильну самооцінку особи керівника.

Управлінська академічна культура розглядається в поєднанні 3 соціальним життям сфери вищої освіти, інтересів членів університетської спільноти та виступає як тип духовної культури і включає всі види, форми й рівні суспільної свідомості, освіту та виховання. Академічна культура управління - це сукупність способів і методів діяльності університетської спільноти, її системна інтегрована якість, що відображає досягнутий рівень розвитку, виступає як сукупність соціальних норм і цінностей, що сформувалися історично і притаманні конкретній інститутській системі; вона включає явища, процеси, відносини, що якісно відрізняють науковопедагогічних працівників, студентів та адміністративно-господарський персонал закладу вищої освіти від інших колективів та соціальних груп.

Здорова академічна культура управління $€$ безцінним капіталом закладу вищої освіти, знаходить своє вираження в писаних і неписаних його нормах, які визнаються університетською спільнотою не стільки 3 огляду на букву законодавства, скільки на дух закладу освіти. Вона охоплює широкий спектр явищ, які регулюють і визначають внутрішнє життя закладу на основі сформованих традиції, усталених норм, академічних звичаїв, які не завжди піддаються універсалізації і створюють неповторний образ університету.

Академічна культура управління за ознаками визначається як сукупність цінностей: наявність в управлінській системі ЗВО формалізованих норм, поглядів, принципів, на основі яких здійснюється управлінська діяльність; існування чіткого і загальноприйнятого уявлення про допустимі для даного закладу та недопустимі методи управлінської діяльності; наявність неформальної комунікації та особових контактів між управлінцями різного рівня, науково-педагогічними працівниками, співробітниками та студентами і як спосіб здійснення цілеспрямованої й раціональної управлінської діяльності: розвинена структура управління, що передбачає наявність спеціалізо- 
ваних підрозділів, які скоординовано діють, виконуючи специфічні завдання, досягаючи загальної мети організації; налагоджена система зворотного зв'язку (від підлеглих до керівництва); систематизація і рефлексія результатів виконання управлінських рішень, їх критична оцінка і коректування; делегування управлінських повноважень; визнання за підлеглими права, виходячи з обставин, коректувати прийняті керівництвом рішення.

Управлінська академічна культура вирішує завдання, що мають важливе значення в системі суспільних відносин взагалі й управлінні закладом вищої освіти зокрема:

- концентрує багаторічний управлінський досвід, створює можливості для його вивчення та засвоєння, передає його новим учасникам, а також транслює його у суспільство;

- визначає стиль керівництва, систему відносин між учасниками управління;

- здійснює вплив на формування й виховання особистості;

- створює можливості ефективно впливати на подолання консерватизму і бюрократизму;

- сприяє розвиткові професійної компетентності керівників та співробітників, підвищенню якості управлінських рішень (як на етапі їх прийняття, так і виконання), значно знижує рівень конфліктності.

Академічна культура управління керівника - це інтегративна динамічна якість особистості, що розвивається в процесі діяльності, характеризується певним рівнем теоретичного осмислення й комплексом практичних умінь та навичок з реалізації підходів до управлінської діяльності на основі безумовного дотримання норм, принципів, моралі. Вона $€$ результатом взаємодії керівника і трудового колективу, впливає на них і трансформується сама. Керівник розкриває через неї свої здібності, світогляд, соціальні почуття, професійні навички; підлеглий, сприймаючи цінності академічної управлінської культури керівника й організації, трансформує власну професійну культуру.

3 іншого боку, академічна культура управління - це відповідність керівника закладу вищої освіти вимогам, що ставляться до управлінської діяльності і до його особистісних якостей, зумовлених нормами й принципами моралі, етики, естетики і права, це високий рівень його особистісної загальної культури управління: сукупність інтелектуальних, професійних, моральних, емоційно-вольових якостей особистості, які дають змогу ефективно вирішувати завдання, визначені суспільними потребами, нормативними актами в даній освітній галузі й забезпечувати високий рівень результативності діяльності керованого ним закладу.

Сучасний ефективний керівник закладу вищої освіти просто зобов'язаний відповідати такому професійному іміджу ідеального управлінця-менеджера: 


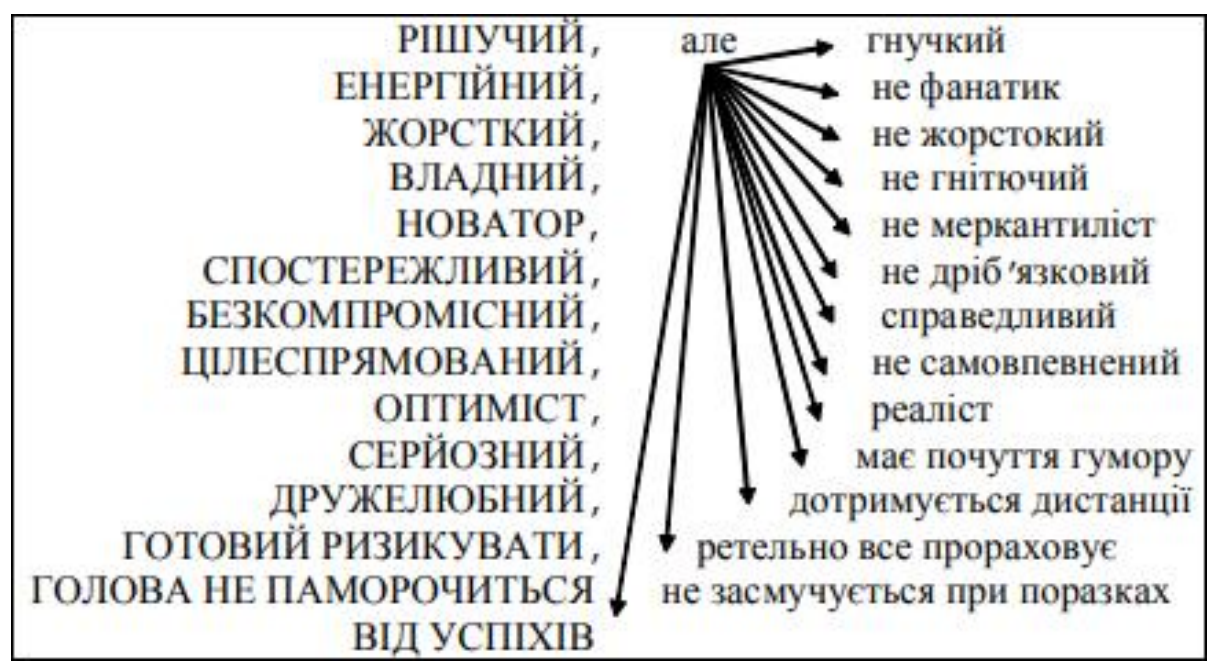

Рис. 1. Риси сучасного управлінця

Досить цікавими $\epsilon$ результати опитування 1500 менеджерів європейських компаній (Библиотека управляющего персоналом: мировой опыт, 1994, с. 95), які засвідчили, що до найважливіших рис керівника відносять такі: здатність формувати ефективну команду - 96 \%; уміння прислухатися до думки колег і підлеглих - 93 \%; здатність приймати рішення 87 \%; уміння залучати інших до виконання прийнятого рішення - 86 \%.

Розвиток академічної культури управління керівника $\epsilon$ складним педагогічним феноменом. Він потребує використання комплексу методологічних підходів, що забезпечать досягнення різнопланових характеристик даного явища. Основними є акмеологічий і модеративний підходи. Ідеї акмеологічного підходу пов'язані з особливістю презентації керівника в акмеології як суб'єкта вдосконалення та саморозвитку через оволодіння керівником ефективними способами управління й самоуправління в аспекті неперервного особистісно-професійного розвитку. Це дозволяє проектувати програми розвитку управлінської культури на рівні само менеджменту. Модеративний підхід передбачає: навчання як комплекс взаємопов'язаних умов, методів і прийомів організації спільної діяльності, що дає змогу залучити учасників до процесу виявлення, осмислення й аналізу складнощів управлінської діяльності, пошуку шляхів їх вирішення, неформального осмислення й поширення досвіду колег, особисту відповідальність кожного учасника управлінського процесу за свої дії та досягнення спільного результату, розвиток здатності до самостійного вирішення проблем, ведення дискусій і переговорів. Методи модерації дають можливість об'єднати учасників, стимулювати до спільного пошуку шляхів вирішення проблеми і підвести їх до переносу знайденого рішення в практичну площину.

Для ініціації тенденції самоменеджменту академічної культури управління доцільно: розвивати командно-колегіальний принцип роботи 3 
участю працівників різних підрозділів для вирішення конкретних завдань і проектів; налагоджувати та вдосконалювати горизонтальні потоки інформації; реалізувати інформаційне забезпечення комунікацій: створення банку іміджевих матеріалів, що включає характеристику кадрового й інтелектуального потенціалу, зв'язку з громадськістю, 3 науковими і культурно-освітніми центрами, відомими вченими, політиками, діячами культури, результати опитування громадської думки тощо; активізацію роботи Веб-сайту ректорату, на якому висвітлюються його традиції, заходи, досягнення, проекти.

Невід'ємною частиною академічної культури управління є процес прийняття управлінського рішення. Саме функція прийняття рішення 3 найбільшою виразністю змушує відчути, що управління - це, звичайно, наука, але й мистецтво теж. Тому культура прийняття рішення дуже важлива для дотримання управлінської діяльності керівника.

Відповідно до того, як керівник взаємодіє з колективом у процесі вироблення рішення, виділяють п'ять рівнів організації управлінських рішень:

- автократичний, що здійснюється безпосередньо керівником, який робить це підкреслено демонстративно, дистанціюючись від підлеглих у процесі прийняття рішення;

- автономний, принцип колегіальності дотримується опосередковано, але істотна й навіть більша частина рішень приймається керівником формально одноосібно;

- локально-колегіальний - керівник залучає інших учасників освітнього процесу до процедури вироблення управлінських рішень, але у процесі прийняття рішення включаються не всі учасники управління, а лише їх частина;

- інтегративно-колегіальний - коли до процесу підготовки і прийняття рішення нормативно включається весь колектив у формі зборів трудового колективу, своєрідних референдумів, конференцій, загальних зборів колективу;

- метаколегіальний - є своєрідним виходом процедури прийняття рішення за межі університету.

Важливою передумовою успішного управління закладом вищої освіти $€$ вміння керівника грамотно делегувати певні повноваження. Щоденний обсяг завдань, який необхідно виконати керівникові, завжди перевищує його фізичні й часові можливості, а доручення справ та завдань підлеглим дозволяє керівникові виконати більший обсяг роботи. Успішний керівник не той, хто може робити будь-яку справу краще за підлеглих, а той, хто керує так, що кожен підлеглий робить свою справу якнайкраще, адже правильний розподіл роботи і відповідальності серед підлеглих $\epsilon$ запорукою успіху управлінської діяльності керівника. 
Делегування повноважень своїм підлеглим $€$ абсолютно необхідним умінням керівника, який відповідає за організацію виконання завдань, адже ефективність управлінської діяльності керівника полягає у здатності використовувати творчі сили учасників освітнього процесу, бути лідером, але при цьому поважаючи, у першу чергу, право інших вирішувати, а це означає передачу частини повноважень на той рівень, де приймаються найбільш ефективні рішення.

Передумовою делегування певних повноважень $\epsilon$ визначення керівником найбільш важливих завдань, які повинні бути вирішені за допомогою підлеглих; створення умов успішного вирішення цих завдань і досягнення намічених цілей; уміння надихнути підлеглих на максимальну самовіддачу при їх розв'язанні.

Існує перелік завдань, які керівник повинен вирішувати тільки сам: стратегічне планування; створення сприятливого мікроклімату в колективі; вирішення конфліктів, та своєчасне їх попередження; оцінка ефективності роботи колективу; контроль за створенням безпечних умов; дисциплінарні заходи; вирішення завдання, що вимагають особливо високої кваліфікації; вирішення фінансових питань з ухвалення кошторису, призначення премії; затвердження рішень, наказів і розпоряджень; завдання, пов'язані 3 конфіденційною інформацією тощо.

Відповідно до ст. 61 Закону України «Про вищу освіту», особами, які навчаються в закладах вищої освіти, є: здобувачі вищої освіти та інші особи (Закон України «Про вищу освіту»). Переважно це молоді люди, а значить університет має бути місцем, де молода людина зможе розвинути свою гідність і прагнення до інтелектуального життя, тому важливим елементом академічної культури управління $€$ волонтерство, яке полягає в готовності жертвувати свій час для громадських справ і робити це безкорисливо. Ураховуючи цю особливість для університетського менеджменту, керівнику при прийнятті на роботу бажаючих працювати, важливо переконатися, чи готова ця людина попрацювати для інших, а не тільки для себе.

Висновки та перспективи подальших наукових розвідок. Отже, теоретично обґрунтувавши сутність поняття академічної культури в контексті їі формування як чинника ефективного управління сучасним університетом, ми дійшли висновку, що академічна культура управління університетом складає його інтелектуально-етичну систему цінностей, мотивацій, переконань та сприйняттів, які визначають професійну діяльність керівника, систему його цінностей, традицій, норм, правил, зразків поведінки, способів діяльності, принципів спілкування, що ґрунтуються на загальнолюдських цінностях; культурі високої духовності й моралі; культурі особливої поведінки і спілкування з підлеглими, колегами, партнерами, студентами, людьми, які професійно покликані забезпечувати виконання делегованих повноважень, передачу культурних цінностей; $\epsilon$ 
культурою високої якості праці керівника і відповідальності за їі результати, за прийняття управлінських рішень; культурою, що є безцінним капіталом закладу вищої освіти, знаходить своє вираження в писаних і неписаних його нормах, які визнаються університетською спільнотою не стільки з огляду на букву законодавства, скільки на дух закладу освіти.

у наших наступних публікаціях розглянемо досвід процесу формування академічної культури в єдності ії складників.

\section{ЛIТЕРАТУРА}

Библиотека управляющего персоналом: мировой опыт. Современный менеджент: теория и практика: Обзорная информация (1994). В. И. Яровой (сост.); Г.В. Щекин (ред.). К.: МзуУП (The library of the manager of personnel: the world experience. M odern M anagement: Theory and Practice: Overview (1994). V. I. Yarova (comp.); H. V. Shchekin (Ed.). K.: M ESUP).

Великий тлумачний словник сучасної української мови (2004). Бусел В. Т. (уклад. і голов. ред.). Київ; Ірпінь: ВТФ «Перун» (The Great Interpretive Dictionary of M odern Ukrainian (2004). V. T. Busel (Ed.). Kyiv; Irpen: Perun).

Гончаренко, С. У. (1997). Український педагогічний словник. К.: Либідь (Honcharenko, S. U. (1997). Ukrainian Pedagogical Dictionary. K.: Lybid).

Добко, Т. (2014). Університет, академічна культура і забезпечення якості. В Т. Добко, М. Головянко, О. Кайкова, В. Терзіян, Т. Тихонен (ред.). Імператив якості: вчимося цінувати і оцінювати вищу освіту, (сс. 58-68). Львів: Манускрипт (Dobko, T. (2014). University, academic culture and quality assurance. In T. Dobko, M. Holovianko, O. Kaikova, V. Terzian, T. Tikhonen (Eds.). The quality imperative: learning to appreciate and evaluate higher education, (pp. 58-68). Lviv: Manuscript).

закон України «Про вищу освіту». Режим доступу: https://zakon.rada.gov.ua/laws/show/1556-18/stru (The Law of Ukraine "On Higher Education". Retrieved from: https://zakon.rada.gov.ua/laws/show/1556-18/stru).

Ковальов, Г. Д. (2000). Інноваційні комунікації. Персонал, 8, 14-19 (Kovalev, H. D. (2000). Innovative communications. Staff, 8, 14-19).

Комаров, А. Элементы формирования кадрового потенциала. Режим доступа: http://www.management.com.ua/ (Komarov, A. Elements of personnel potential formation. Retrieved from: http://www. management.com.ua/).

Королюк, С. В. (2003). Управлінська культура керівника школи. Постметодика, 5-6, 8588 (Koroliuk, S. V. (2003). Managerial culture of the head of the school. Postmethodics, 5-6, 85-88).

Мельник, В. К. (2003). Підвищення управлінської кваліфікації керівника загальноосвітнього навчального закладу в системі післядипломної педагогічної освіти (дис. ... канд. пед. наук: 13.00.01). К. (M elnyk, V. К. (2003). Improvement of managerial qualification of the head of a comprehensive education institution in the system of postgraduate pedagogical education (PhD thesis). K.).

Салова, Т. Б. (2013). Оцінювання персоналу в системі управління. Електронний збірник наукових праць Національної академії державного управління, 2 (Salova, T. B. (2013). Evaluation of personnel in the management system. Electronic Collection of Scientific Papers of the National Academy of Public Administration, 2).

Святоха, Н. А. (2013). Вплив управлінської культури керівника вищого навчального закладу на ефективність менеджменту. Теоретичні і прикладні проблеми психології, 3, 227-233 (Sviatokha, N. A. (2013). The influence of the managerial 
culture of the head of a higher education institution on the effectiveness of management. Theoretical and Applied Problems of Psychology, 3, 227-233).

Ярковой, О. М. (2002). Педагогічні засади розвитку управлінської культури державних службовців в умовах післядипломної освіти (автореф. дис. ... канд. пед. наук: 13.00.05). X. (Yarkova, O. M. (2002). Pedagogical bases of development of managerial culture of civil servants in the conditions of postgraduate education (DSC thesis abstract). $X$.

\section{PEЗЮME}

Пшеничная Любовь. Академическая культура как составляющая эффективного управления современным университетом.

Статья посвящена проблеме исследования академической культуры, её теоретическому обоснованию, определению сущности понятия в контексте её формирования как составляющей эфрфективного управления современным университетом. Для достижения поставленной цели исследованы методологические и теоретические основы управления, сделаны выводы о том, что управление и менеджмент составляют синонимические ряды: практику деятельности человека, профессию, науку, процесс деятельности, людей, которые осуществляют управление, органы управления.

Процесс управления рассмотрен как вид деятельности, который обеспечивает оптимальное функционирование и развитие системы, согласовывает и координирует деятельность людей для достижения общей цели, поскольку успешная деятельность университета в условиях автономии требует системного переосмысления подходов к нему, как на уровне учебного процесса, так и в маситабах целого университета.

Ключевые слова: академическая культура, культура управления, менеджент, сфера деятельности, университет, профессиональная деятельность руководителя, системный подход.

\section{SUMMARY}

Pshenydhna Lubov. Academic culture as an effective factor of the modern university management.

The article is devoted to the research of academic culture, its theoretical substantiation, the concept definition in its formation context as an effective factor of the modern university management. To achieve this goal, the methodological and theoretical bases of management are investigated, and the conclusions are made that administration and management are synonymous: human activity practice, profession, science, activity process, people who do management, management body.

The management process is considered as an activity type that ensures the optimal systems functioning and development, coordinates the people activities in the common goal pursuit, thus the successful university activity in terms of autonomy, a systematic approaches rethinking at the educational process level and at the whole university scale are required.

In the study context, the concept "culture" is considered as a universal property of people's social life in different spheres of their activity and a phenomenon, which is an instrument of successful activity of the organization, leader, staff, and every employee managerial culture.

Academic management culture is disclosed as a set of methods and the university community methods, its systematic integrated quality, reflecting achieved development level, 
acts as social norms and values set that have been historically formed and have been inherent in a particular institute system. It includes phenomena, processes, relations that qualitatively distinguish scientific and pedagogical workers, students and administrative staff of a higher education institution from other social groups and is a priceless capital of a higher education institution.

It was investigated that development of academic management culture is a complex pedagogical phenomenon, which is defined as a set of values and as a way of implementing purposeful and rational management activities, which requires using of the methodological approaches set to achieve the goal.

Key words: academic culture, management culture, management, activity sphere, university, manager's professional activity, system approach.

\section{УДК 378.147}

Галина Райковська

Державний університет «Житомирська політехніка» ORCID ID 0000-0003-1755-9516

Андрій Шостачук

Державний університет «Житомирська політехніка» ORCID ID 0000-0002-4924-1222

DOI 10.24139/2312-5993/2019.08/288-296

\section{ЗАДАЧІ ГЕОМЕТРИЧНОГО МОДЕЛЮВАННЯ МЕХАНІЗМІВ У ПРОФЕСІЙНІЙ ПІДГОТОВЦІ БАКАЛАВРІВ-МЕХАНІКІВ}

у даній статті обгрунтовано важливість навчання майбутніх бакалаврівмеханіків геометричному моделюванню. Запропоновано класифікацію задач геометричного моделювання, відповідно до якої всі задачі можна розділити на три групи: проектування нових механізмів, дослідження механізмів, модернізація та оптимізація механізмів. Представлено короткий зміст кожної задачі. Наведено вхідні та вихідні параметри, які мають місце відповідно при постановці задачі геометричного моделювання та в результаті ї̈ розв'язання. Детально розглянуто зміст і порядок розв'язання задач, присвячених тертю та зношуванню поверхонь, коливанням у механізмах та застосуванню методів інженерної творчості.

Ключові слова: механізм, геометричне моделювання, аналіз, синтез, кінематика, точність, коливання, оптимізація, тертя та зношування, інженерна творчість.

Постановка проблеми. Сучасні темпи появи нової та модернізація наявної техніки вимагають від інженера-механіка виконання відповідальних проектів та надійних розрахунків у максимально стислі терміни. На сьогодні є доступними програмні продукти, які дозволяють такі дослідження проводити в 3D просторі. Однією з переваг 3D моделей $\epsilon$ наочність у порівнянні з плоскими малюнками. Відповідно, при підготовці бакалаврів-механіків необхідно в навчальному процесі передбачити можливість розв'язування актуальних задач із дослідження механізмів сучасних технологічних та транспортних машин, використовуючи при 